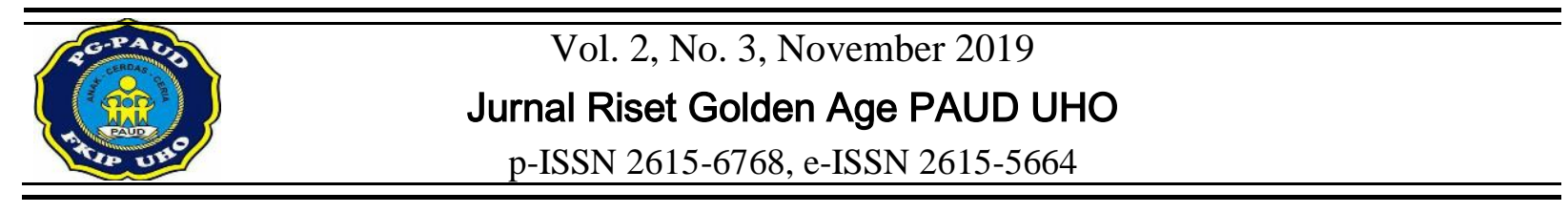

\title{
MENINGKATKAN KEMAMPUAN MOTORIK KASAR MELALUI PERMAINAN
} LARI ESTAFET

\author{
Rurin Dwiningsih ${ }^{1)}$, Aisyah ${ }^{1)}$, Husain Ibrahim ${ }^{1)}$ \\ ${ }^{1}$ Jurusan PG-PAUD, Universitas Halu Oleo. Jln. H.E.A Mokodompit, Kendari 93232, \\ Indonesia.
}

\begin{abstract}
Abstrak
Penelitian ini bertujuan untuk meningkatkan kemampuan motorik kasar melalui permainan lari estafet di Kelompok B TK Negeri Melati Mekar Kecamatan Wolasi Kabupaten Konawe Selatan. Subjek dalam penelitian ini adalah guru dan anak di Kelompok B TK Negeri Melati Mekar Kecamatan Wolasi Kabupaten Konawe Selatan. Jenis penelitian ini adalah penelitian tindakan kelas. Berdasarkan analisis data hasil observasi aktivitas mengajar guru pada siklus I diperoleh ketercapaian sebesar $71,43 \%$, pada aktivitas belajar anak didik siklus I diperoleh ketercapaian sebesar 64,29\%, pada hasil belajar anak didik pada siklus I diperoleh persentase sebesar 68,75\%. Sedangkan pada siklus II hasil aktivitas mengajar guru meningkat menjadi 92,86\%, aktivitas belajar anak didik pada siklus II meningkat menjadi $85,71 \%$, hasil belajar anak didik meningkat sebesar $93,75 \%$
\end{abstract}

Kata kunci: Motorik Kasar, Permainan, Lari Estafet

\section{IMPROVING ROUGH MOTOR ABILITY THROUGH RELAY RUNNING GAMES}

\begin{abstract}
This research aims to improve the rough motor skills through the relay run game in the group $B$ TK Negeri Melati Mekar Wolasi District of South Konawe district. The subject in this study was teacher and child in group B TK Negeri Melati Mekar Wolasi District of South Konawe district. This type of research is class action research. Based on a data analysis of the observation of the teacher's teaching activity on cycle I gained $71.43 \%$ of achievement, in the study activities of the cycle I gained the achievement by $64.29 \%$, on the outcome of learning students in the I-cycle gained Percentage of $68.75 \%$. While in cycle II the results of teacher teaching activity increased to $92.86 \%$, students ' study activities in cycle II increased to $85.71 \%$, student learning results increased by $93.75 \%$.
\end{abstract}

Keywords: Rough Motor, Game, Relay

\section{PENDAHULUAN}

Undang-Undang Pendidikan Republik Indonesia No. 20 Tahun 2003 tentang Sistem Pendidikan Nasional Pasal 1 ayat 14 menyatakan bahwa Pendidikan Anak Usia Dini adalah suatu upaya pembinaan yang ditujukan kepada anak sejak lahir sampai dengan usia enam tahun yang dilakukan melalui pemberian rangsangan pendidikan untuk membantu pertumbuhan dan perkembangan jasmani dan rohani agar anak memiliki kesiapan dalam memasuki pendidikan lebih lanjut (Depdiknas, 2003).

Salah satu kemampuan perkembangan anak usia dini yang harus ditingkatkan yaitu perkembangan motorik kasar anak. Kemampuan motorik kasar adalah kemampuan yang berkaitan erat dengan koordinasi, keseimbangan, kekuatan, otot-otot besar. Kemampuan motorik kasar diperlukan oleh anak dalam rangka melakukan kegiatan-kegiatan di luar ruangan yang membutuhkan kemampuan otot besar.

Perkembangan motorik dapat juga disebut sebagian perkembangan dari unsur kematangan dan pengendalian gerak tubuh. Perkembangan motorik ini erat kaitannya dengan perkembangan pusat motorik di otak. Oleh karena itu, setiap gerakan yang dilakukan anak sesederhana apapun, sebenarnya merupakan pola interaksi yang kompleks dan sistem dalam tubuh yang dikontrol otak, Kematangan syaraf akan mempengaruhi gerakan motorik anak (Syafi'i, 2007: 1.3)

Prinsip perkembangan motorik menurut Yudha M. Saputra dan Rudyanto (2005: 116) 
adanya suatu perubahan baik fisik maupun psikis sesuai dengan masa pertumbuhan serta perkembangan motorik sangat dipengaruhi oleh gizi, status kesehatan, dan perlakuan motorik yang sesuai dengan masa perkembangannya.

Seiring dengan pertumbuhan fisiknya yang beranjak matang, maka perkembangan motorik anak sudah dapat terkoordinasi dengan baik setiap gerakan anak sudah selaras dengan kebutuhan atau minatnya. Anak menggerakkan anggota badannya dengan tujuan yang jelas seperti menggerakkan tangan untuk menulis, menggambar, mengambil makanan, menggerakan kaki untuk menendang bola, lari mengejar teman dan sebagainya (Syamsu Yusuf dan Nani Sugandi, 2015: 59).

Sumantri (2005: 271), motorik kasar merupakan keterampilan yang bercirikan gerak yang melibatkan sekelompok otot-otot besar sebagai dasar utama geraknya. Santrock (2009: 209) menyatakan bahwa keterampilan motorik kasar (gross motor skill) merupakan keterampilan yang melibatkan aktivitas otot besar seperti tangan seorang anak untuk bergerak dan kaki untuk berjalan, sedangkan menurut Decaprio (2013: 18) juga berpendapat bahwa motorik kasar adalah gerakan tubuh yang menggunakan otot-otot besar atau sebagian otot yang ada dalam tubuh maupun seluruh anggota tubuh yang dipengaruhi oleh kematangan diri.

Samsudin (2008: 9), motorik kasar adalah kemampuan anak TK beraktivitas dengan menggunakan otot-otot besar. kemampuan menggunakan otot-otot ini bagi anak TK tergolong pada kemampuan gerak dasar dibagi menjadi tiga kategori, yaitu: lokomotor, non lokomotor, dan manipulatif.

Beaty di kutip oleh Fadlillah dan Khorida, (2013: 59) Kemampuan motorik kasar seorang anak dapat dilihat melalui empat aspek, yaitu a) berjalan atau walking, dengan indikator turun naik tangga dengan menggunakan ke dua kaki, berjalan pada garis lurus dan berdiri satu kaki ; b) berlari atau running, dengan indikator menunjukkan kekuatan dan kecepatan berlari, berbelok ke kanan-kiri tanpa kesulitan dan mampu berhenti dengan mudah; c) melompat atau jumping, dengan indikator mampu melompat ke depan, ke belakang, dan ke samping; dan d) memanjat atau climbing, dengan indikator memanjat naik- turun tangga dan memanjat pepohonan.

Berdasarkan observasi awal yang dilakukan di TK Negeri Melati Mekar Kecamatan Wolasi Kabupaten Konawe Selatan, bahwa kegiatan yang dilakukan di luar ruangan merupakan kegiatan yang jarang dilakukan oleh murid di TK tersebut. Dilihat dari 16 orang anak di kelompok B, yang belum mengalami peningkatan motorik kasar sebesar 56,25\%.

Bertitik tolak pada paparan permasalahan tersebut, maka perlu dirancang suatu permainan yang menarik bagi anak untuk meningkatkan motorik kasar anak. Peneliti merasa perlu untuk menggunakan sebuah permainan yaitu permainan lari estafet.

Lari estafet adalah lari yang paling menyenangkan dalam program atletik. Para pelari mengkombinasikan kecepatan, koordinasi, dan kerja sama tim (Guthrie, 2008:79). Khomsin dalam Ermawati (2008: 33) mengatakan lari estafet adalah salah satu nomor lari yang sering diperlombakan dalam cabang atletik, yaitu lari sambung dengan jumlah masing-masing regu berjumlah 4 orang atlet, di mana pelari pertama harus membawa tongkat yang diberikan pada pelari ke 2 , ke 3 , dan pelari ke 4 dengan pengoperan tongkat yang sesuai peraturan yang berlaku.

Pada nomor lari sambung ada kekhususan yang tidak akan dijumpai pada nomor pelari lain, yaitu memindahkan tongkat sambil berlari cepat dari pelari sebelumnya ke pelari berikutnya. dalam melakukan lari sambung bukan teknik saja yang diperlukan tetapi pemberian dan penerimaan tongkat di zona atau daerah pergantian serta penyesuaian jarak dan kecepatan dari setiapa lari.

Sujiono (2008: 1.19-1.24) menyebutkan bahwa bermain estafet juga memiliki tujuan yang baik untuk anak usia dini antara lain, yaitu: (1) melatih ketangkasan, (2) melatih meningkatkan koordinasi, (3) melatih kecepatan, (4) melatih sikap kerja sama, (5) melatih kelincahan. Dengan demikian bermain estafet apabila dikembangkan sangat memiliki banyak manfaat untuk anak-anak baik dalam menjalankan aktivitas belajar dalam bermain maupun dalam melakukan kegiatan sehari-hari dapat berjalan secara optimal.

\section{METODE}

Jenis penelitian yang digunakan dalam penelitian ini adalah Penelitian Tindakan Kelas (PTK). Menurut Kusumah dan Dwitagama (2012: 9) penelitian tindakan kelas (PTK) adalah penelitian yang dilakukan oleh guru di kelasnya sendiri dengan cara merencanakan, melaksanakan, merefleksikan tindakan secara kolaboratif dan partisipan dengan tujuan 
memperbaiki kinerja sebagai guru, sehingga hasil belajar siswa dapat meningkat.

Penelitian ini dilaksanakan pada Kelompok B TK Negeri Melati Mekar Kecamatan Wolasi Kabupaten Konawe Selatan. Penelitian dilaksanakan pada semester ganjil tahun ajaran 2018/2019.

Subjek dalam penelitian ini adalah anak kelompok B TK Negeri Melati Mekar Kecamatan Wolasi Kabupaten Konawe Selatan yang berjumlah 16 orang anak yang terdiri dari 8 orang anak laki-laki dan 8 orang anak perempuan.

Adapun faktor-faktor yang diteliti dan diamati dalam penelitian ini adalah: a) faktor anak didik, mengamati aktivitas anak dalam meningkatkan kemampuan motorik kasar anak melalui permainan lari estafet dan b) faktor guru, mengamati dan memperhatikan segala aktivitas guru yang mempersiapkan dan melaksanakan kegiatan pembelajaran dalam meningkatkan kemampuan motorik kasar anak melalui permainan lari estafet.

Data yang diperoleh dari penelitian ini adalah data kualitatif dan data kuantitatif. Data kualitatif digunakan untuk menghimpun data tentang pelaksanaan proses pembelajaran yang dilaksanakan oleh guru dan anak. Data kualitatif diperoleh melalui lembar observasi. Sedangkan data kuantitatif menghimpun data tentang peningkatan kemampuan motorik kasar anak melalui permainan lari estafet yang diperoleh melalui lembar instrumen/evaluasi yang dilakukan pada setiap pertemuan dan diakhir siklus tindakan.

Analisis data merupakan cara yang dilakukan untuk mengetahui keefektifan suatu metode dalam kegiatan pembelajaran (Aqib, 2009:203).

Pengelolaan data dalam penelitian ini disesuaikan dengan teknik penilaian di TK yaitu dengan menggunakan tanda sebagai berikut: Belum Berkembang $(\mathrm{BB})=*$, Mulai Berkembang $(\mathrm{MB})=* *$, Berkembang Sesuai Harapan $=* * *$,Berkembang Sangat Baik $=* * * *$ (Depdiknas, 2004: 26).

Tabel 1. Kategori Keberhasilan Klasikal

\begin{tabular}{rcc}
\hline \multicolumn{1}{l}{ Persentase } & Kategori & Simbol \\
\hline $95 \%-100 \%$ & $(\mathrm{BSB})$ & $* * * *$ \\
\hline $85 \%-94 \%$ & $(\mathrm{BSH})$ & $* * *$ \\
\hline $75 \%-84 \%$ & $(\mathrm{MB})$ & $* *$ \\
\hline$<75 \%$ & $(\mathrm{BB})$ & $*$ \\
\hline
\end{tabular}

Dari segi indikator hasil, tindakan dikatakan berhasil apabila anak didik telah mencapai nilai berkembang sesuai harapan (BSH) dan berkembang sangat baik (BSB) minimal $85 \%$ baik secara individual maupun klasikal.

\section{HASIL DAN PEMBAHASAN}

Sebelum kegiatan ini dilakukan, peneliti terlebih dahulu melakukan pertemuan dengan Kepala Sekolah TK Negeri Melati Mekar Kecamatan Wolasi Kabupaten Konawe Selatan pada tanggal 2 Oktober 2018. Pertemuan ini bermaksud untuk menyampaikan tujuan dari peneliti yaitu mengadakan penelitian di TK Negeri Melati Mekar Kecamatan Wolasi Kabupaten Konawe Selatan. Selanjutnya kepala Sekolah TK Negeri Melati Mekar Kecamatan Wolasi Kabupaten Konawe Selatan mengarahakan langsung peneliti untuk berdiskusi dengan guru kelompok $\mathrm{B}$ berkaitan dengan kegiatan yang akan dilakukan peneliti dalam meningkatkan motorik kasar melalui permainan lari estafet.

Setelah itu, peneliti melakukan observasi awal di sekolah tersebut, khususnya Kelompok B untuk mengetahui keadaan awal pengembangan kemampuan motorik kasar anak. Hasil observasi tentang perkembangan motorik kasar anak belum maksimal. Hal ini disebabkan karena pembelajaran yang dilakukan di luar kelas merupakan kegiatan yang jarang dilakukan oleh anak.

Berdasarkan permasalahan yang dihadapi tersebut, maka peneliti berusaha menghadirkan sebuah permainan yang menarik dan menyenangkan bagi anak untuk dilaksanakan di luar ruangan untuk meningkatkan kemampuan kemampuan motorik kasar anak yaitu permainan lari estafet. Selanjutnya, peneliti bersama guru TK Negeri Melati Mekar Kecamatan Wolasi Kabupaten Konawe Selatan sepakat untuk berkolaborasi dan menjadi mitra dalam kegiatan penelitian ini.

Penelitian dilakukan dengan tindakan siklus I yang terdiri dari 4 kali pertemuan dan mengikuti empat tahapan kegiatan yaitu perencanaan, pelakanaan tindakan, observasi dan evaluasi, dan refleksi. Hal-hal yang dilakukan dalam tahap ini adalah menyiapkan RPPH dan RPPM, media yang dibutuhkan, lembar observasi anak dan guru serta alat evaluasi/penilaian.

Pelakasanaan tindakan siklus I pertemuan I dilaksanakan pada hari selasa 9 Oktober 2018 
dengan tema binatang sub tema macam-macam binatang darat (ayam). Pada pelaksanaan tindakan ini, peneliti melaksanakan pembelajaran pada RPPH siklus I, yaitu sebelum kegiatan pembelajaran dimulai peneliti atau guru menyambut kedatangan setiap anak dengan apel pagi yang dipimpin oleh seorang guru yang mendapat piket. Pada saat berbaris anak-anak didik diatur secara rapi setelah itu guru tidak lupa mengajak anak untuk bernyanyi "lonceng berbunyi" setelah menyanyi guru menanyakan kepada anak tentang kondisi anak pada hari itu, serta guru menanyakan tentang hari, tanggal, bulan, tahun. Setelah anak berbaris guru langsung mempersilahkan anak untuk masuk kelas masing-masing.

Pada kegiatan inti di siklus I pertemuan I dalam meningkatkan kemampuan motorik kasar anak, terlebih dahulu peneliti menjelaskan tema dan sub tema serta permainan lari esatafet kepada anak, setelah menjelaskan tema dan sub tema peneliti langsung memberikan contoh cara melakukan permainan lari estafet. terdapat 4 orang anak yang melakukan posisi start dengan benar, 7 orang anak yang dapat memegang erat tongkat agar tidak terlepas, 9 orang anak yang dapat menjaga keseimbangan tubuh pada saat berlari, dan 5 orang anak yang melakukan permainan lari sesuai dengan aturan yang telah ditetapkan.

Kegiatan akhir yaitu peneliti melakukan tanya jawab kepada anak mengenai kegiatan yang telah dilakukan. Selanjutnya peneliti mempersiapkan anak untuk pulang serta membimbing anak bernyanyi bersama, berdoa,dan salam.

Pelaksanaan tindakan siklus I pertemuan II dilaksanakan pada hari rabu 10 Oktober 2018 dengan tema binatang sub tema macam-macam binatang darat (sapi). pada pelaksanaan tindakan siklus I pertemuan II, peneliti melaksanakan pembelajaran pada Rencana Pelaksanaan Pembelajaran Harian (RPPH) siklus I, yaitu sebelum kegiatan pembelajaran dimulai, guru atau peneliti menyambut setiap kedatangan anak untuk apel pagi. Sebelum kegiatan pembelajaran dimulai terlebih dahulu anak-anak apel pagi di depan kelas yang dipimpin oleh seorang guru piket. Setelah barisan anak didik rapi, anak-anak dipersilahkan masuk kedalam kelas, akan tetapi anak-anak kelompok B langsung diarahkan menuju lapangan untuk melakukan kegiatan.

Pada kegiatan inti siklus I pertemuan II, peneliti melakukan review tentang pelajaran yang telah dilakukan sebelumnya yaitu pemahaman anak tentang permainan lari estafet. Selanjutnya peneliti langsung membagi anak ke dalam beberapa kelompok atau regu. Pada saat melakukan pembagian kelompok ada beberapa anak yang susah diatur akan tetapi hal tersebut dapat diatasi. Selanjutnya setelah anak-anak di bagi dalam beberapa kelompok atau regu kegiatan langsung berjalan dengan lancar. Pada siklus I pertemuan II ada 10 orang anak yang memegang erat tongkat agar tidak terlepas, sedangkan anak yang melakukan posisi star dengan benar sebanyak 6 orang anak, serta anak yang menjaga keseimbangan tubuh pada saat berlari sebanyak 13 orang anak, dan yang melakukan permainan lari sesuai dengan aturan yang telah ditetapkan sebanyak 5 orang anak.

Setelah kegiatan selesai peneliti mempersilahkan anak untuk istirahat, selanjutnya anak masuk dalam ruangan untuk bersiap pulang, sebelum pulang peneliti membimbing anak untuk membaca doa pulang, dan membaca surah-surah pendek, dan pulang.

\section{Pertemuan III}

Pelaksanaan tindakan siklus I pertemuan III dilaksanakan pada hari kamis 11 Oktober 2018 dengan tema binatang dan sub tema macam-macam binatang darat (kambing). Pada pelaksanaan tindakan ini, peneliti melaksanakan pembelajaran pada RPPH siklus I, yaitu sebelum kegiatan pembelajaran dimulai, guru dan peneliti menyambut kedatangan anak ke sekolah kemudian kegiatan selanjutnya yaitu apel pagi. Anak-anak berbaris diluar halaman kelas yang dipimpin oleh salah satu guru yang mendapat piket. Setelah barisan anak didik rapi, guru langsung mempersilahkan anak untuk masuk kelas masing-masing akan tetapi anak kelompok B langsung diarahkan menuju lapangan untuk melaksanakan kegiatan seperti yang mereka lakukan sebelumnya.

Pada kegiatan inti di siklus I pertemuan III peneliti melakukan review yakni menanyakan kembali kepada anak mengenai permainan lari estafet yang sudah mereka lakukan sebelumnya. Selanjutnya peneliti memberikan contoh permainan lari estafet tentang bagaimana melakukan posisi start, apaapa saja aturan permainan yang ada. Setelah menjelaskan anak-anak langsung melakukan kegiatan. Anak yang menjaga keseimbangan tubuh pada saat berlari sebanyak 15 orang anak, sedangkan anak yang melakukan posisi star dengan benar sebnyak 8 orang anak, dan anak 
yang memegang erta tongkat agar tidak terlepas sebanyak 11 orang anak, serta anak yang melakukan permainan lari sesuai dengan aturan yang telah ditetapkan yaitu 7 orang anak.

Selanjutnya setelah anak-anak melakukan kegiatan langsung saja peneliti mengarahkan anak-anak untuk makan dan mempersilahkan juga anak untuk bermain atau istirahat. Selanjutnya anak di masukkan di dalam ruangan untuk bersiap pulang, sebelum pulang guru menyimpulkan kegiatan yang telah di lakukan anak. Setelah peneliti menyimpulkan kegiatan langsung saja peneliti membimbing anak membaca surah-surah pendek, doa pulang, beserta mengucapkan salam.

Pelaksanaan tindakan siklus I pertemuan IV, dilaksanakan pada hari jumat 12 Oktober dengan menggunakan tema binatang dan sub tema macam-macam binatang darat (kelinci) Pada pelaksanaan tindakan ini, peneliti melaksanakan pembelajaran pada RPPH siklus I. dimulai peneliti atau guru menyambut kedatangan setiap anak, kemudian apel pagi yang dipimpin oleh salah satu guru yang mendapat piket. Pada saat berbaris anak-anak didik diatur secara rapi kemudian guru tidak lupa menanyakan kondisi anak pada hari itu serta menanyakan hari, tanggal, bulan, serta tahun.

Pada kegiatan inti di siklus I pertemuan IV seperti biasa peneliti mengarahkan anak langsung menuju lapangan untuk melakukan kegiatan permainan fisik. Sebelum Peneliti membagi anak ke dalam beberapa kelompok, terlebih dahulu peneliti menanyakan kabar anak serta kagiatan yang telah dilakukan kemarin. Kegiatan selanjutnya akan di laksanakan yaitu melakukan kegiatan permainan lari estafet. terdapat 8 orang anak yang dapat melakukan posisi star dengan benar, sedangkan anak yang mmegang erat tongkat agar tidak terlepas sebanyak 11 orang anak, dan anak yang melakukan permainan lari estafet sesuai dengan aturan yang ditetapkan sebanyak 7 orang anak, dan 16 orang anak yang menjaga keseimbangan tubuh pada saat berlari.

Setelah kegiatan selesai anak langsung dipersilahkan untuk istirahat. Kemudian peneliti melakukan tanya jawab kepada anak mengenai kegiatan yang telah dilakukan. Setelah itu peneliti membimbing anak membaca surahsurah pendek, membaca doa pulang, menyanyi, salam dan pulang.

Selama proses pembelajaran berlangsung, guru sebagai observer mengamati jalannya pembelajaran dengan menggunakan lembar observasi untuk guru dan lembar observasi untuk anak. Kegiatan observasi dilakukan bersamaan dengan pelaksanaan tindakan untuk setiap pertemuan pada siklus I.

Hasil observasi guru sesuai dengan pedoman lembar observasi sebanyak 14 aspek yang harus dicapai oleh guru. Pada siklus 1 skor yang dicapai oleh guru dari 14 aspek hanya 10 aspek atau $71,43 \%$ adapun aspek yang tercapai diantaranya sebagai berikut: (1) guru menyiapkan media dalam proses pembelajaran, (2) guru mengucapkan salam, (3) guru menyampaikan tugas yang akan dilakukan, (4) guru menyampaikan tema dan sub tema, (5) guru memberikan bimbingan kepada anak dalam melakukan permainan, (6) guru memperlihatkan dan menjelaskan media yang akan digunakan, (7) guru memberikan contoh kepada anak dalam melakukan permainan lari estafet, (8) guru mengadakan tanya jawab mengenai kegiatan awal sampai akhir kegiatan, (9) guru menyimpulkan kegiatan yang telah dilakukan, (10) guru membimbing anak untuk pulang. Untuk lebih jelasnya dapat dilihat pada diagram berikut:

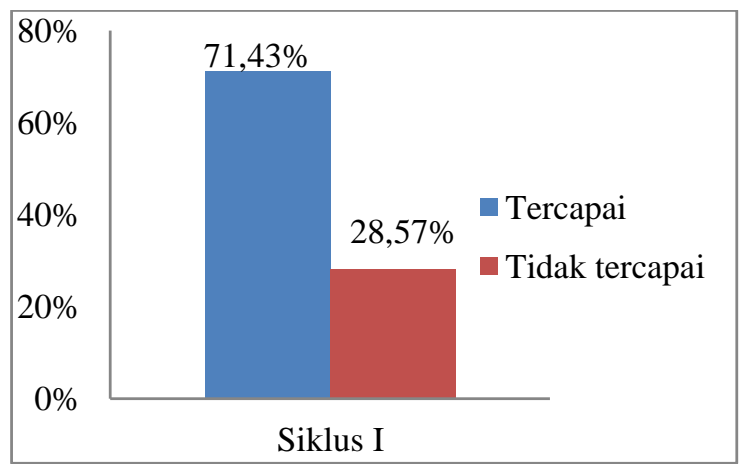

Gambar 1. Diagram Hasil Analisis Aktivitas Mengajar Guru Siklus I

Observasi yang dilakukan pada aktivitas belajar anak pada siklus I yang diamati observer menggunakan lembar observasi aktivitas belajar anak yang terdiri dari 14 aspek. Pada siklus I baru sekitar 9 aspek saja yang tercapai atau sekitar 64,29\% diantaranya sebagai berikut: (1) anak menjawab salam (2) anak berbaris di depan kelas, (3) anak berdoa sebelum belajar (4) anak siap untuk belajar (5) anak memperhatikan guru menyampaikan kegiatan pembelajaran, (6) anak memperhatikan media yang akan digunakan, (7) anak melakukan permainan lari estafet setelah dicontohkan oleh guru, (8) anak memperhatikan guru memberikan contoh bermain lari estafet, 
(9) anak mengikuti arahan dari guru untuk pembagian kelompok. Untuk lebih jelasnya dapat dilihat pada diagram berikut:

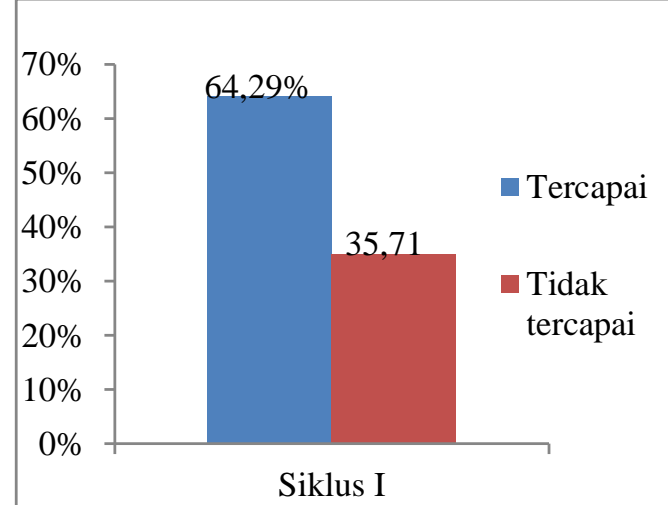

Gambar 2. Diagram Hasil Analisis Aktivitas Belajar Anak Didik Siklus I

Tabel 1. Nilai Klasikal pada Siklus I

\begin{tabular}{lcc}
\hline \multicolumn{1}{c}{ Kategori } & $\begin{array}{c}\text { Jumlah } \\
\text { Anak }\end{array}$ & $\begin{array}{c}\text { Persentase } \\
(\%)\end{array}$ \\
\hline $\begin{array}{l}\text { Berkembang } \\
\text { Sangat Baik }\end{array}$ & 0 & 0 \\
\hline $\begin{array}{l}\text { Berkembang } \\
\text { Sesuai Harapan }\end{array}$ & 11 & 68,75 \\
\hline $\begin{array}{l}\text { Mulai } \\
\text { Berkembang }\end{array}$ & 5 & 31,25 \\
\hline $\begin{array}{l}\text { Belum } \\
\text { Berkembang }\end{array}$ & 0 & 0 \\
\hline Jumlah & 13 & 100 \\
\hline
\end{tabular}

Berdasarkan hasil yang diperoleh pada Tabel 1. terlihat bahwa secara klasikal kegiatan meningkatkan kemampuan motorik kasar anak melalui permainan lari estafet sebagian besar anak sudah dapat melaksanakan kegiatan dengan baik yaitu $68,75 \%$ anak memperoleh nilai BSB dan BSH namun belum mencapai indikator kinerja yang ditetapkan yaitu $85 \%$ anak memperoleh nilai BSB dan BSH. Oleh karena itu, guru dan peneliti mendiskusikan kekurangan-kekurangan apa saja yang terdapat pada pelaksanaan tindakan siklus I untuk kemudian diperbaiki dan dilaksanakan pada siklus II.

Dari hasil observasi, maka beberapa hal yang harus diperbaiki adalah guru harus menyampaikan tujuan pembelajaran setiap kali pertemuan, guru harus memberikan motivasi, penguatan, serta penghargaan kepada anak agar anak lebih semangat lagi dalam melaksanakan kegiatan, guru juga harus lebih semangat untuk menceritakan kepada anak hal-hal yang menarik mengenai kegiatan yang akan dilakukan agar hasil belajar anak didik di siklus II diharapkan dapat mencapai indikator kinerja $85 \%$.

Pelakasanaan tindakan siklus II pertemuan I dilaksanakan pada hari selasa 16 Oktober 2018 dengan tema binatang sub tema macam-macam binatang (kupu-kupu) Pada pelaksanaan tindakan ini, peneliti melaksanakan pembelajaran yaitu sebelum kegiatan pembelajaran dimulai peneliti atau guru menyambut kedatangan setiap anak, kemudian apel pagi yang dipimpin oleh seorang guru yang piket. Pada saat berbaris anak-anak didik diatur secara rapi setelah itu guru tidak lupa mengajak anak untuk bernyanyi "lonceng berbunyi" setelah menyanyi gurumenanyakan kepada anak tentang kondisi anak pada hari itu, tidak lupa juga guru menanyakan tentang hari, tanggal, bulan, serta tahun. Setelah anak berbaris guru langsung mempersilahkan anak untuk masuk kelas masing-masing akan tetapi anak kelompok B diarahkan langsung menuju lapangan untuk melakukan kegiatan dalam hal meningkatkan kemampuan motorik kasar.

Pada kegiatan inti di siklus II pertemuan I dalam meningkatkan kemampuan motorik kasar anak, peneliti menjelaskan kembali materi tentang permainan lari estafet serta macammacam binatang (kupu-kupu) dengan memperlihatkan gambar kupu-kupu yang ada pada tongkat peneliti langsung menjelaskan kembali kepada anak anak tentang teknik permainan lari estafet. setelah itu, peneliti mengarahkan anak-anak untuk melakukan kegiatan tersebut. Kemudian anak-anak mengambil posisi, ada yang mendapat posisi pertama, ada juga anak yang mendapat posisi ke dua, dan seterusnya. Jumlah anak yang melakukan permainan lari sesuai dengan aturan yang telah ditetapkan sebanyak 8 orang anak, dan anak yang melakukan posisi star dengan benar sebanyak 8 orang anak, dan 11 orang anak yang memegang erat tongkat agar tidak terlepas, dan 16 orang anak yang menjaga keseimbangan tubuh pada saat berlari.

Kegiatan akhir yaitu peneliti menyimpulkan kegiatan yang telah dilakukan hari ini serta peneliti mengadakan tanya jawab mengenai kegiatan dari awal sampai akhir kegiatan. Selanjutnya peneliti memberikan motivasi kepada anak. Serta menyiapkan anak untuk pulang dengan bernyanyi bersama serta berdoa dan pulang.

Pelaksanaan tindakan siklus II pertemuan II dilaksanakan pada hari rabu 17 Oktober 2018 
dengan tema binatang sub tema macam-macam binatang (lalat). Pada pelaksanaan tindakan siklus II pertemuan II, peneliti melaksanakan pembelajaran seperti biasa yaitu sebelum kegiatan pembelajaran dimulai, peneliti telah menyiapkan media pembelajaran yang akan digunakan dalam pembelajaran tentang motorik kasar melalui permainan lari estafet. Sebelum kegiatan pembelajaran dimulai terlebih dahulu anak-anak apel pagi di depan kelas yang dipimpin oleh seorang guru piket. Setelah barisan anak didik rapi, anak-anak dipersilahkan masuk kedalam kelas akan tetapi anak kelompok B lagi-lagi diarahkan untuk menuju lapangan.

Pada kegiatan inti siklus II pertemuan II, guru melakukan review tentang pelajaran yang telah dilakukan sebelumnya yaitu pemahaman anak tentang cara melakukan permainan lari estafet. peneliti kembali memberikan contoh kepada anak dalam melakukan permaian lari estafet setelah itu peneliti membagi anak-anak kedalam beberapa kelompok untuk melaksanakan kegiatan. Dimana jumlah anak yang melakukan posisi start dengan benar sebanyak 10 orang anak, dan anak yang memegang erta tongkat agar tidak terlepas sebanyak 14 orang anak, dan 16 orang anak yang menjaga keseimbangan tubuh pada saat berlari, serta 10 anak yang melakukan permainan lari sesuai dengan aturan yang telah ditentukan.

Kegiatan akhir yaitu anak masuk dalam ruangan untuk bersiap pulang, sebelum pulang guru selalu memberikan motivasi-motivasi kepada anak serta menyimpulkan kegiatan dari awal sampai akhir kegiatan. Guru membimbing anak untuk membaca doa pulang, dan membaca surah-surah pendek, serta salam.

Pelaksanaan tindakan siklus II pertemuan III dilaksanakan pada hari kamis 18 Oktober 2018 dengan tema binatang dan sub tema macam-macam binatang (nyamuk). Pada pelaksanaan tindakan ini, guru melaksanakan pembelajaranyaitu sebelum kegiatan pembelajaran dimulai, guru telah menyiapkan media pembelajaran terlebih dahulu berupa tongkat estafet. guru dan peneliti menyambut kedatangan anak ke sekolah kemudian kegiatan selanjutnya yaitu apel pagi. Anak-anak berbaris diluar halaman kelas yang dipimpin oleh seorang guru piket. Setelah barisan anak didik rapi, lagi dan lagi anak kelompok A dipersilahkan untuk masuk kelas sedangkan anak kelompok B diarahkan langsung menuju tempat kegiatan untuk melaksanakan pembelajaran seperti biasanya.

Pada kegiatan inti di siklus II pertemuan III seperti sebelumnya peneliti melakukan review yakni menanyakan kepada anak mengenai permainan lari estafet. Selanjutnya peneliti langsung membagi anak-anak kedalam beberapa kelompok dan anak-anak bergegas untuk mengambil posisi masing-masing ada yang mendapat posisi pertama, dan ada yang mendapat posisi ke dua dan seterusnya. Jumlah anak yang melakukan permainan lari estafet dengan benar sebanyak 12 orang anak, dan 14 orang anak yang memegang erat tongkat agar tidak terlepas, dan 16 orang anak yang dapat menjaga keseimbangan tubuh pada saat berlari, serta 12 orang anak yang melakukan permainan lari sesuai aturan yang telah ditetapkan.

Kegiatan akhir yaitu anak dimasukkan di dalam ruangan untuk bersiap pulang, sebelum pulang peneliti memberikan motivasi kepada anak agar lebih semangat lagi dalam melakukan kegiatan tersebut. Peneliti juga menyimpulkan kegiatan yang telah di lakukan anak kemudian peneliti mengadakan tanya jawab dengan anak mengenai kegiatan dari awal sampai akhir. peneliti membimbing anak membaca surahsurah pendek, doa pulang, serta mengucapkan salam.

Pelaksanaan tindakan siklus II pertemuan IV, dilaksanakan pada hari jumat 19 Oktober dengan menggunakan tema binatang dan sub tema macam-macam binatang (belalang). Pada pelaksanaan tindakan ini, guru melaksanakan pembelajaran yaitu peneliti atau guru menyambut kedatangan setiap anak kemudian apel pagi yang dipimpin oleh seorang guru piket. Pada saat berbaris anak-anak didik diatur secara rapi kemudian guru menanyakan kondisi anak pada hari itu serta menanyakan hari, tanggal, bulan, serta tahun kemudian anak di ajak bernyanyi.

Pada kegiatan inti di siklus II pertemuan IV peneliti langsung mengarahkan anak untuk menuju lapangan untuk melakukan kegiatan permainan lari estafet. Peneliti mengarahkan anak untuk melakukan permainan lari estafet. jumlah anak yang melakukan posisi start dengan benar sebanyak 13 orang anak, dan anak yang memegang erat tongkat agar tidak terlepas yaitu 14 orang anak, serta 16 orang anak yang menjaga keseimbangan tubuh pada saat berlari, dan yang melakukan permainan lari sesuai dengan aturan yang telah ditetapkan sebanyak 12 orang anak. 
Kegiatan akhir yaitu peneliti mengadakan tanya jawab kembali kepada anak mengenai kegiatan yang sudah dilakukan. Setelah itu peneliti membimbing anak membaca surahsurah pendek, membaca doa pulang, menyanyi, salam dan pulang.

Selama proses pembelajaran berlangsung, guru sebagai observer mengamati jalannya pembelajaran dengan menggunakn lembar observasi untuk guru dan lembar observasi untuk anak. Kegiatan observasi dilakukan bersamaan dengan pelaksanaan tindakan untuk setiap pertemuan pada siklus II.

Hasil observasi guru sesuai dengan pedoman lembar observasi sebanyak 14 aspek yang harus dicapai oleh guru. Pada siklus II skor yang dicapai oleh guru dari 14 aspek hanya 13 aspek atau 92,85\% aspek yang tercapai diantaranya sebagai berikut: (1) guru menyatakan sesuatu yang menenagkan kelas, (2) guru mengucapkan salam, (3) guru menyampaikan tugas yang akan di lakukan, (4) guru menyampaikan tema dan sub tema, (5) guru menyiapkan media, (6) guru memperlihatkan dan menjelaskan media yang akan digunakan, (7) guru memberikan bimbingan kepada anak dalam melakukan permainan, (8) guru memberikan contoh kepada anak dalam melakukan permainan lari estafet, (9) guru menyimpulkan kegiatan yang dilakaukan, (10) guru menyampaikan tujuan pembelajaran, (11) guru mengadakan tanya jawab, (12) guru memberikan motivasi, penguatan, serta penghargaan, (13) guru membimbing anak untuk pulang. Untuk lebih jelasnya dapat dilihat pada diagram berikut:

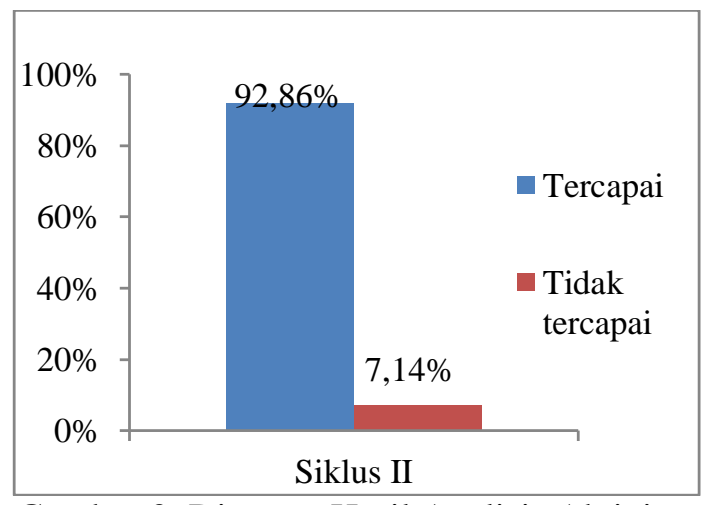

Gambar 3. Diagram Hasil Analisis Aktivitas Mengajar Guru Siklus II

Observasi yang dilakukan pada aktivitas belajar anak pada siklus II yang diamati observer menggunakan lembar observasi aktivitas belajar anak yang terdiri dari 14 aspek. Pada siklus II hanya 12 aspek saja yang tercapai diantaranya: (1) anak menjawab salam dari guru (2) anak berdoa sebelum belajar (3) anak berbaris di depan kelas, (4) anak siap untuk belajar, (5) mendengarkan nasihat yang disampaikan oleh guru, (6) anak memperhatikan guru menyampaikan kegiatan yang akan dilakukan, (7) anak memperhatikan media yang akan digunakan, (8) anak melakukan kegiatan permainan lari estafet setelah dicontohkan oleh guru, (9) anak memperhatikan guru memberikan contoh bermain lari estafet, (10) anak mengikuti arahan dari guru untuk pembagian kelompok (11) anak mendengarkan motivasi dari guru, (12) anak mendengarkan guru menyimpulkan kegiatan yang telah dilakukan. Untuk lebih jelasnya dapat dilihat pada diagram berikut:

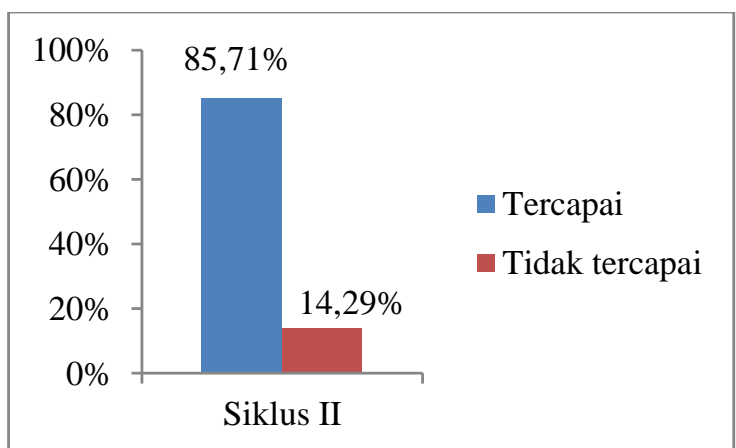

Gambar 4. Diagram Hasil Analisis Aktivitas Belajar Anak Didik Siklus II

Tabel 2. Nilai Klasikal pada Siklus II

\begin{tabular}{|c|c|c|}
\hline Kategori & $\begin{array}{c}\text { Jumlah } \\
\text { Anak }\end{array}$ & $\begin{array}{c}\text { Persentase } \\
(\%)\end{array}$ \\
\hline $\begin{array}{l}\text { Berkembang } \\
\text { Sangat Baik }\end{array}$ & 5 & 31,2 \\
\hline $\begin{array}{l}\text { Berkembang } \\
\text { Sesuai Harapan }\end{array}$ & 10 & 62,5 \\
\hline $\begin{array}{l}\text { Mulai } \\
\text { Berkembang }\end{array}$ & 1 & 6,25 \\
\hline $\begin{array}{l}\text { Belum } \\
\text { Berkembang }\end{array}$ & 0 & 0 \\
\hline Jumlah & 20 & 100 \\
\hline
\end{tabular}

Berdasarkan data hasil perolehan nilai anak didik yang ditampilkan pada Tabel 2, maka dapat disimpulkan bahwa secara klasikal perolehan nilai anak didik dalam kegiatan meningkatkan kemampuan motorik kasar anak melalui permainan lari estafet pada Kelompok B mengalami peningkatan, karena tingkat keberhasilan anak didik yaitu sebesar 85\% memperoleh nilai $\mathrm{BSH}$ dan BSB, dapat 
dikatakan bahwa sebagian besar anak didik dipandang telah mampu menyelesaikan tugastugas yang telah ditetapkan sesuai dengan indikator penilaian khususnya dalam pelaksanaan tindakan siklus II.

Jika dilihat dari pemahaman anak didik mulai dari pelaksanaan siklus I sebesar 68,75\% jika dibandingkan pada tahapan observasi awal/prasiklus penelitian yang hanya mencapai $43,75 \%$ dan pada tindakan siklus II mencapai persentase sebesar $93,75 \%$, menunjukkan hasil yang lebih baik dari sebelumnya, karena indikator kinerja yang ditetapkan telah tercapai yaitu minimal $85 \%$ maka peneliti dan guru sepakat bahwa penelitian ini dapat dihentikan sampai pada siklus II.

\section{KESIMPULAN DAN SARAN}

\section{Kesimpulan}

Observasi awal anak didik yang memperoleh nilai ketuntasan secara klasikal $43,75 \% .7$ orang yang mendapat nilai (***) atau Berkembang Sesuai Harapan (BSH). Pada siklus I mencapai $68,75 \%$ dimana hanya 11 orang anak yang mendapat nilai (***) atau Berkembang Sesuai Harapan. Selanjutnya pada siklus II diperoleh nilai ketuntasan secara klasikal 93,75\%. Dimana $31,25 \%$ atau 5 orang anak didik yang mendapat nilai $(* * * *)$ atau Berkembang Sangat Baik (BSB) dan 62,5\% atau 11 orang anak didik mendapat nilai $(* * *)$ atau Berkembang Sesuai Harapan (BSH) dan anak yang mendapat nilai $(* *)$ atau Mulai Berkembang (MB) sebanyak 1 orang anak didik atau $6,25 \%$.

Hasil observasi aktivitas mengajar guru pada sikluls I memperoleh persentase keberhasilan sebesar $71,43 \%$ dan hasil observasi aktivitas belajar anak didik pada siklus I memperoleh presentase keberhasilan 64,29\%. Selanjutnya pada siklus II aktivitas mengajar guru memperoleh presentase keberhasilan sebesar $92,86 \%$ dan hasil aktivitas observasi aktivitas belajar anak sebesar $85,71 \%$.

\section{Saran}

Setelah melaksanakan tindakan penelitian maka peneliti menyarankan hal-hal diantaranya dalam pelaksanaan pembelajaran maka hendaknya mempertimbangkan materi, media, dan strategi yang tepat untuk anak didik dan guru dituntut untuk selalu kreatif dan inovatif dalam melaksanakan kegiatan-kegiatan yang dapat meningkatkan potensi anak didik.

\section{DAFTAR PUSTAKA}

Aqib, Zainal. 2009. Penelitian Tindakan Kelas. Bandung: CV. Yrama Widya.

Decaprio, R. 2013. Aplikasi teori pembelajaran motorik di sekolah. Yogyakarta: Diva Press.

Depdiknas. 2003. Undang-Undang RI No. 20 Tahun 2003. Sistematis Pendidikan Nasional. Jakarta: Citra Umbara.

Depdiknas. 2004. Kerangka Dasar Kurikulum 2004. Jakarta: Departemen Pendidikan Nasional.

Eni, Ermawati. 2015. Upaya Meningkatkan Motorik Kasar Pada Anak Melalui Permainan Balap Karung Estafet Pada Kelompok BI Paud Supriyadi Semarang. PAUDIA:Jurnal Penelitian dalam Bidang Pendidikan Anak Usia Dini, 8 (1), 153168.

Fadillah, Muhammad dan Lilif Mualifatu Khorida. 2013. Pendidikan Karakter Anak Usia Dini Konsep Dan Aplikasinya Dalam PAUD. Yogyakarta: Ar-Ruzz Media.

Guthrie, M. 2008. Sukses Melatih Atletik.Yogyakarta: PT Pustaka Insan Madani.

Kusumah, Wijaya dan Dedi Dwitagama. 2012. Mengenal Penelitian Tindakan. Kelas. Jakarta: PT Indeks.

Samsudin. 2008. Pembelajaran Motorik di Taman Kanak-Kanak. Jakarta: Prenada Media Group.

Santrock, J.W. 2009. Psikologi Pendidikan Edisi 3 Buku 2.Terjemahan: Diana Angelica. Jakarta: Salemba Humanika.

Saputra, Yudha. M \& Rudyanto 2005. Pembelajaran Kooperatif Untuk Meningkatkan Keterampilan Anak TK. Jakarta: Departemen Pendidikan.

Sujiono, Bambang. 2008. Metode Pengembangan Fisik. Jakarta: Universitas Terbuka.

Sumantri, MS. 2005. Model Pengembangan Keteranpilan Motorik Anak Usia Dini. Jakarta :Depdiknas 
Rurin Dwiningsih, Aisyah, Husain Ibrahim / Jurnal Riset Golden Age PAUD UHO 2 (3) (2019)

Syafi'i. 2007. Psikologi Perkembangan Anak

Dan Remaja. Bandung: PT Remaja Rosdakarya.

Yusuf, Syamsu dan Nani Sugandi. 2016. Perkembangan Peserta Didik. Jakarta: PT. Raja Gravindo Persada. 